\title{
Negligence and the General Problem of Criminal Responsibility*
}

\section{Introduction}

It is a central feature of all modern systems of criminal law that the individual's liability to punishment, at least in the case of serious offenses, is made conditional upon the absence of certain inental conditions', taking this term in a wide sense. These conditions are often conceptualized negatively as excuses or excusing conditions since they serve to relieve the individual of liability even though it is acknowledged that he engaged in some act condemned by the law. Thus, as a general matter, a man is not subject to punishment if at the time of his offense he was, among other things, (i) mistaken about some material fact regarding the circumstances he was in, (ii) unaware of what the consequences of his acts would be, (iii) unconscious or in a trance, (iv) unable to control his muscular movements (as, for example, occurs in epilepsy), (v) insane, (vi) an infant or (vii) subject to certain forms of coercion or duress. It is true, of course, that no legal system recognizes all these excusing conditions (and others of a similar character) in all cases and without qualification. Compromises are struck, most often in cases where it is believed that extreme difficulties of proof would otherwise result or where some overriding consideration of public policy or public safety is present. Such compromises are exemplified in our law, respectively, by conclusive 'evidentiary' presumptions such as "every sane man intends the natural and probable consequences of his acts"1 and by the mass of public welfare offenses which has grown up over the last century as the result of legislation.?

* The author wishes to thank Mr. A. M. Quinton of New College, Oxford for his great assistance in the preparation of an carlicr version of this Note.

1. See, e.g., Director of Public Prosecutions v. Smith, [1961] A.C. 290, where such a conclusive presumption was applied to a defendant charged with murder. The cffect of the presumption is, of course, to cxclude the defense of " 110 intention" once certain facts are proved. As Lord Kilmuir put the point in Smith: "Once . . the jury are satisfied [that the accused voluntarily engaged in an unlawful act direeted at another person] it matters not what the accused in fact contemplated as the probable result or whether he cver contemplated at all .... [T] he sole question is whether the unlawful and voluntan act was of such a kind that gricvous bodily harm was the natural and probable result. The only test available for this is what the ordinary ... man would . . hase content. plated as the natural and probable result." Id. at 327 (emphasis added). Ifter a prolonged and heated national debate, the Smith Case was overruled by I'arliament. Sec Criminal Justice Act 1967, $\$ 8$.

2. These offenses-all of which involve strict liability-first appeared in .Inglo. American law slightly more than a hundred years ago. The desigmation 'public wellare" derives from the fact that all of the early statutes defining such offenses were aimed at 
Nevertheless, the recognition of mental excusing conditions is the rule rather than the exception in modern criminal law. And because it is the rule, and also-perhaps exactly-because exceptions to it are regarded as 'compromises', the over-all practice of conditioning linbility on excuses is often construed as a reflection in the law of a quite general principle of social life, namely: that a man is not responsible for a wrong he has committed unless, in some way, his 'mind' or 'will' can be implicated in the offense.

This principle of responsibility may best be explained by reference to the following, somewhat Cartesian, figure. If a person is conceived as an embodied mind or will, a distinction may be drawn between two questions regarding the appraisal of his conduct. The first question is: Has he, judged solely by his outward conduct, engaged in some kind of wrongdoing or brought about some harmful result? The second question is: How closely connected with such wrongdoing or harm was his (embodied) mind or will? ${ }^{3}$ To what extent was he the author of the wrong or harm involved? It is considerations bearing on this second question which are in issue when the question of responsibility is raised, and, as a general matter, such considerations become relevant only after it is already established that a person has done something wrong. ${ }^{4}$ This principle of responsibility is represented in AngloAmerican criminal law by the doctrine of mens rea, a doctrine which entered the common law several centuries ago via the Latin maxim: actus non facit reum nisi mens sit rea. This maxim has been rendered into English as "an act does not make a person guilty unless the mind is guilty." $\mathrm{It}$ is because this maxim is an integral part of our law that courts in England and America regularly make inquiries into such matters as the state of a defendant's knowledge at the time of his offense, the capacity he possessed to control his muscular movement, his sanity, etc. before deciding the issue of his liability to punishment. And if it is found, for example, that a defendant did lack some material bit of knowledge at the time of his unfortunate conduct or was unable to control his muscular movements or was insane, these facts will

practices posing a broad and serious threat to public safety or the public good, c'st, sale of adulterated food, sale of narcotics, violation of building regulations, etc. See generally J. Hall, General Principles of Criminal law 327-31 (2d ed. 1960) [hereinafier cited as HALL].

3. H. L. A. Hart, Punishment and Responsibility 221 (1968) [hercinafter cited as HART].

4. There are some exceptions to this rule. See Goldstcin \& Katz, Abolish the "Insanity Defense"-Why Not?, 72 YALE L.J. 853, 864 (1963), where the authors point out that on retrial in the celebrated case of Durham v. United States, 214 F.2d 862 (D.C. Cir. 1954), the issue of insanity was submitted to the jury before the issuc of guilt or innocence.

5. R. Cross \& P. A. Jones, AN Introduction to Criminal Liw 30 (5th cd. 1961) [hereinafter cited as Cross \& JoNEs]. 
generally be sufficient to ground a complete acquittal. In orthodox legal parlance it is said that the 'subjective element' necessnry for liability has not been shown; or, more simply, that because some excusing condition was present, no mens rea existed."

Exactly why the law does, and ought to, refrain from applying its sanctions to offenders who lack mens rea is a matter of some controversy. Utilitarians of one kind or another have maintained since the time of Bentham that such a practice is justified by its practical effects measured against the standard of utility. ${ }^{7}$ It is now a widely held view among legal philosophers, however, that irrespective of the injunctions of the utilitarian calculus, a justification may be made out for the practice of requiring mens rea as a condition of criminal liability on the basis of ordinary, non-utilitarian, notions of justice and fairness. ${ }^{8}$ Nor does this require a wholesale subscription to the views of traditional 'retributivism'. The argument, in outline form, runs as follows. Even if one agrees that the underlying justification of criminal punishment is utilitarian in character, it does not follow from this that there are no other (independent) values 'in play' in the punishment situation. In fact, there is at least one such value, fairness, and it serves, among other things, to restrict the range of subjects against whom the law may properly direct its sanctions. Thus, even if it might be justified on utilitarian grounds, in some hypothetical situation, to punish a man who has done nothing wrong, this would be precluded by considerations of fairness. 9 Similarly, the argument continues, it is unfair to punish a man who has done something wrong if, at the time, he was laboring under a mistake and did not know what he was doing, or could not control his bodily movements, or for some other reason was totally devoid of mens rea. Although these two situations are different in a number of important respects, the moral protest in each is the same: the innocent must not be made to suffer punishment.

It is this principle which underlies the mens rea requirement in criminal law, and one need not look very far to uncover its roots. Punishment, whether in a legal context or not, is a distinctive human activity. It involves not only the infliction of suffering on an indi-

6. For express judicial recognition of 'insanity' as a mental condition which ncgatives mens rea or 'guilty mind', sec United States v. Currens, 290 F.2d 751, 773 (3d Cir. 1901).

7. J. Bentham, Priscilles of Morals and Legislation, Ch. 13, Sce. 3 (W. Harrison cd. 1960).

8. See, e.g., HART 17-22 and 48-49.

9. Id. at 11-12. There arc, of course, a small numbur of offenses of this hind recognized in Anglo-American law. Crimes of "vicarious liability" provide the most conspicuous example. See Cross \& Jones $96-98$ and J. SMitit \& B. Hor.Av, Crivinil Laly 98-103 (2d cd. 1969) [hereinafter cited as SMrril \& Hocsix]. 
vidual, but also an extreme form of condemnation. It is typically in situations such as this, i.e., situations in which harsh burdens are to be distributed and/or individuals are to be held up to scorn, that rules of restraint and just desert are developed by human society. Such rules become embodied in the practices and speech of ordinary life, and give rise to claims of one kind and another. Standards evolve. Thus it is not every regrettable act that will bring down upon a man the wrath of his fellows. Perhaps it was a mistake or an accident; or perhaps the actor could not help himself. These discriminations are deeply embedded in human attitudes. Nor is this particularly surprising. As a trenchant Mr. Justice Holmes once remarked, "even a dog distinguishes between being stumbled over and being kicked."10

If it is now widely agreed that criminal punishment requires a subjective element if it is not to offend against common notions of fairness, it is by no means widely agreed what this subjective element is. The answer of the common law, as was noted earlier, is that it is a mens rea or 'guilty mind'. But exactly what is a guilty mind? How intimately connected must an individual's mind be with some mis. conduct he has engaged in or some harmful result he has brought about in order that he be justly held liable in the criminal law for that misconduct or harm ${ }^{11}$ There are, of course, clear cases at both ends of the spectrum. If a sane man in ordinary circumstances deliberately acts in a way he knows to be illegal, he has acted with mens rea. On this point there can be no dispute; if mens rea means anything, it means this. At the opposite end of things, if a man is held liable for bringing about some result which, at the time, neither he nor any reilsonable man could possibly have foreseen, this is a case of strict linbility. And then there are the 'middle' cases. In particular there is one middle case, that of negligence, which has proved inordinately troublesome to legal theorists. Indeed, much of the jurisprudential discussion of the general problem of criminal responsibility in the last twenty years has centered on the seemingly narrow question of whether negligence is a form of mens rea or whether to admit negligence as a basis of liability in the criminal law amounts to strict liability. ${ }^{12}$ Con-

10. O. W. Holmes, The Common Law 7 (M. Howe cd. 1963).

11. This formulation of the 'question of responsibility' is adequatc for newaly all kinds of crimes. There are certain aberrant cases, however, for which it will not do, e.g., crintes of vicarious liability or certain crimes of status where liability for the offense is not predicated upon any conduct the accused engaged in (see R. v. Larsonncur, 149 Lit R. (n.s.) 542 (1933). These cases are expressly excluded from consideration herc.

12. See, e.g., HaLc Ch. 4; Hall, Negligent Behavior Should Be Excluded From Penal Liability, 63 Colum. L. REv. 632 (1963); HarT Ch. 6; Turner, The Mental Element in 
sideration of this question has led theorists not only to the formulation of precise standards of responsibility for the criminal law, but also, concomitantly, to the formulation of quite general theories as to the nature of criminal guilt, i.e., of that subjective element which, under ordinary notions of fairness, makes punishment tolerable. The reason for this seems obvious. As with so many other problems in the law, theorizing is unnecessary when only clear cases must be dealt with. It is when the limiting case arises that careful analysis of a doctrinal character becomes indispensable.

One of the most ingenious theoretical accounts of the concept of criminal guilt put forward in recent years is that advanced by Professor H. L. A. Hart in a now celebrated essay entitled Negligence, Mens Rea and Criminal Responsibility. ${ }^{13}$ Hart's essay has been enormously influential, and deservedly so. ${ }^{14}$ Like many of his other works, it is a kind of paradigm of lucidity and elegance in jurisprudential writing. Whether the account of criminal guilt it contains is in all respects satisfactory is, of course, another matter, and one which will be given extensive consideration here. Before turning to this question, however, it may be wise to make a few brief remarks concerning the nature of negligence and its role in the criminal law.

\section{Negligence in the Criminal Law}

The term 'negligence', as it is used in the criminal law, has a dual reference. It refers (i) to certain forms of outward conduct and (ii) to a kind or species of mental 'culpability' (to adopt the Model Penal Code's formulation). ${ }^{15}$ These two senses of 'negligence', although related in certain contexts, are in principle quite different and should be kept apart. Negligence in the first sense denotes "conduct which is deemed by the law to be unreasonably dangerous," that is, conduct which is unreasonably likely to cause harm. ${ }^{10}$ The criterion used by the law in making this determination is the standard of safe conduct observed by the 'reasonable man' or, as it is sometimes put, by the

Crimes at Common Law, in The Modern Aprodcit to Cruanal. LAw (L. Radzinowicz \& J.W.C. Turner eds. 1945); and especially Fletcher. The Theory of Criminal Negligence: A Comparative Analysis, 119 U. PA. L. REv. 401 (1971).

13. HART Ch. 6.

14. See, e.g., SMith \& Hogan 57; Cross \& JoNes 43; and especially P. Bretr, AN INQuIRY INTO CRIMINaL GuILT 99-100 (1963) and Fletcher, supra note 12, at 415.26. Thus far Hart's approach to negligence has not been followed in any case, bul cf. R. v. Hudson, [1965] I All E.R. 721 (C.C.A.).

15. Model Penal Code $\$ 2.02$ (Proposed Official Draft, 1962).

16. Edgerton, Negligence, Inadvertence, and Indifference; The Relation of Mental States to Negligence, 39 HARv. L. REv. 849, 852 (1926). 
"man of ordinary prudence, acting prudently." This criterion is frequently termed the 'negligence standard'. ${ }^{17}$

The negligence standard is most often made use of in the criminal law in connection with offenses which involve, by their terms, the infliction of injury by one person upon another. ${ }^{18}$ The most dramatic example of this is the crime of manslaughter in English law. Manslaughter, of course, requires the death of another person. But it is not every act which gives rise to the death of another person that amounts to manslaughter. The act must be, considering all the circumstances, an unreasonable one, a negligent act. It must involve a departure from the standard ot safe conduct which a reasonable man would observe. Moreover, because of the seriousness of this offensc, the British courts have demanded that this departure be a wide onc. Only gross negligence or negligence of a "very high degree" will sustain a conviction for manslaughter. ${ }^{10}$ The degree to which an action is negligent depends upon the circumstances in which it is done. Thus, to cite a famous illustration, if a workman repairing a roof flings down a heavy stone into the street and kills a man, this may be either misadventure (non-culpable accidental homicide) or manslaughter. "If it were in a country village, where few passengers are, and he calls out to all people to have a care, it is misadventure only; but if it were in London, or other populous town, where people are continually passing, it is manslaughter, though he gives loud warning . . ..." The circumstances in each case determine the degree to which the action departs from the standard of reasonable safety, and hence whether it is sufficiently negligent to constitute manslaughter.

By using the negligence standard to define offenses such as manslaughter, the criminal law places upon the individual a kind of sub. sidiary duty to avoid dangerous conduct. The duty is subsidiary in both the sense (i) that it exists solely in virtue of the existence of a primary duty (e.g., in manslaughter, not to cause the death of another person) and in the sense (ii) that its violation is punishable only when the harm prohibited by the primary duty results. This sub-

17. Conduct which conforms to the 'negligence standard' is commonly reforted to as 'due care', this expression meaning only reasonably safe conduct. The expression 'duc care', in this use, does not describe a mental state or mental condition of any kind. See id. at 852 .

18. There are exceptions to this rulc. The English offense of 'driving without due care and attention' (Road Traffic Act 1960, $\$ 2(1)$ ), commonly known as 'carcless driving', may be committed although no injury is actually inflicted. Sec SMrrn \& Hocin 332.

19. See id. at 222-26; Cross \& Jones 152. The leading cases on this point are $R, v$. Bateman, [1925] All E.R. 45 (C.C.A.) and Andrews v. Director of Public P'rosecutions, [1937] A.C. 576 .

20. 4 W. Blackstone, Commentaries * 192. 
sidiary duty is sometimes expressed as the duty to take reasonable precautions against harm, and for the vast majority of cases this formulation is perfectly adequate. Thus, to return for a moment to the illustration set out above, if a workman flings down a heavy stone into the street of a country village, where there are "few passengers," his conduct is not unreasonable if he first takes the precaution of shouting out a warning-or at least his conduct is not so unreasonable as to constitute criminal negligence, i.e., negligence sufficiently gross to ground a conviction for manslaughter. On the other hand, if he is working in the city, the duty to take reasonable precautions against harm requires more of him than this. It may require, for example, that he close off the section of street beneath his work place or post danger warnings or both. The subsidiary duty to take rensonable precautions against harm is thus a variable duty. It serves, however, in all cases, to set a minimum standard of safe conduct below which the individual may not fall. This standard is, moreover, an 'external' one in two distinct senses. Firstly, it is external in the sense that it is not fixed by reference to the individual capacities or characteristics of the actor, but by reference to those of a (hypothetical) normal or reasonable man. ${ }^{21}$ Secondly, the standard is external in the sense that what it evaluates is outward conduct alone, and not any mental state or mental process.22 It is solely in respect of his actions that the individunl complies with or falls below the standard, although, as will be seen presently, a failure to comply with the standard will often-but not always -constitute grounds for inferring some mental shortcoming on the actor's part.

It was noted at the outset of this section that the term 'negligence', as it is used in the criminal law, refers not only to certain forms of dangerous conduct, but also to a kind or species of 'mental culpability'. And it is 'negligence' in this second sense which must now be considered. Although negligence as a form of 'mental culpability' involves matters quite different from those considered above (in connection with negligence as 'unreasonably dangerous conduct'), it too may best be explained by reference to the situation in which one individual causes injury to another. When a man has broken the law, say by bringing about some form of prohibited harm, he may have done so, from the point of view of mental culpability, in one of three ways,

21. There may be some exceptions to this rule (at least in the civil law) if the actor is sufficiently 'abnormal'. For example, in many jurisdictions a child is not held to the 'reasonable man' standard, but to one which takes account of his youth and inexperience.

22. See Edgerton, supra note 16, at 852-59. 
viz. intentionally, recklessly, or negligently. ${ }^{23} \mathrm{~A}$ man acts (i) intentionally with respect to some harm if he knows, to a practical certainty, that his conduct will bring it about; (ii) recklessly, if he knows that his conduct creates a substantial and unjustified risk of bringing it about; and (iii) negligently, if he does not know of such a risk, but an ordinary man of reasonable prudence would. Thus, it is often said that intention consists in knowledge, recklessness in conscious risk creation, and negligence in inadvertence amounting to fault. ${ }^{24}$ These three species of mental culpability are not only mutually exclusive, but also involve different degrees of blameworthiness. It is worse to bring about some injury intentionally than recklessly, and worse to bring it about recklessly than negligently. For this reason the law often creates a number of different offenses, all of which prohibit the same harm, but which vary in degree of seriousness. Thus, the Model Penal Code recognizes three distinct forms of unlawful homicide: murder (intention), manslaughter (recklessness), and negligent homicide, each of which carries a different maximum sentence. ${ }^{20}$

It is important at this point to note some of the characteristics of negligence as a species of mental culpability. In the first place, unlike both intention and recklessness, negligence does not involve any awareness by the individual that he is doing something wrong. Indeed, half the point of saying that an offense was committed negligently is to exclude this possibility. That is why criminal law writers sometimes use the expression 'inadvertent negligence' instend of simply saying 'negligence'. It is not, however, the case that a man is guilty of negligence every time he engages in some untoward act without realizing what he is doing or what the consequences will be. It must also be true that, under the circumstances, a man of ordinary intelligence and reasonable prudence would have so realized. In other words, an individual is guilty of negligence only when he fails to know some fact or foresee some consequence of his conduct which a reasonable man, similarly situated, would have known or foreseen. It is this failure which constitutes negligence as a species of mental culpability. Negligence in this sense is, of course, related in certain contexts to negligence in the sense of unreasonably dangerous conduct. When it

23. The Model Penal Code distinguishes two forms of 'intentional' wrongdoing: (i) 'purposely' and (ii) 'knowingly' (corresponding to the older distinction betwecn dirce't and oblique intention). Model Peval CODE $\$ 2.02$ (Proposed Official Draft, 1962)، Botli ill the Code and in practice, however, 'knowledge' and 'purpose' are treated as equivalent bases of liability for most offenses. The major cxception occurs in the law of attellpts. See id. $\$ 5.01$.

24. See, e.g., id. $\$ 2.02$, Comment (Tent. Draft No. 4, 1955).

25. Id. $\S \S 210.2$ through 210.4 and $\S 6.06$. 
man acts in a dangerous way, it is often because he does not know some fact about the circumstances he is in or because he fails to realize what his conduct will lead to. The two, however, are not the same. Nor is it always possible to infer from the fact that a man has acted in a dangerous manner that he did not know some fact about his surroundings or did not realize what the likely result of his conduct would be. It is unfortunately true that individuals sometimes inflict harm on others intentionally or as the result of taking a calculated, but unjustified, risk.

Finally, negligence as a species of mental culpability is not confined in its use by the law to situations or offenses involving physical harm or injury. Quite the contrary, unlike its behavioral analog, it has a broad application across the spectrum of crimes. Every time an individual's liability to punishment is predicated upon his failure to know some fact which a reasonable man, similarly situated, would have known or to foresee some consequence a reasonable man would have foreseen or to make some judgment a reasonable man would have made, he is held, in effect, for negligence, whether that term is used or not. Such failures have been held sufficient, in varying circumstances, to ground liability for offenses as diverse as abduction, bigamy, and non-repair of a highway. ${ }^{26}$ Indeed, although negligence may not provide so wide a basis of criminal liability as Justice Holmes once suggested, ${ }^{27}$ it is by no means an overstatement to say that it penetrates, in one way or another, nearly every corner of the criminal law. Thus, the question of whether negligence constitutes a fair basis for the imposition of criminal sanctions-or whether it amounts to a form of strict liability-is one of quite general importance and implications. Of course, this question is presented most dramatically in connection with offenses such as manslaughter which involve gross forms of harm and severe penalties. It is in this context of harm-doing that it will be considered below.

26. See Smith \& Hogan 55 (abduction); id. at 485 (bigamy); and G. Willuams, Conmisal. Law: The General PART 115 (2d ed. 1961) [hereinafter cited as W'Hulavis] (non-repair of a highway). In the case of abduction and bigamy, negligence is a sufficicnt basis of liability as a result of the application of the 'reasonable mistake' rulc, which provides that a mistake of fact-no matter how honest and sincere-will not excuse unless it is also reasonable, i.e., unless it is of such a character that an ordinary 'reasonable man' could also have made it. This rule, which qualifies the more general rule that a mistalie of fact simpliciter excuses, has been applied with increasing frequency in recent years. This has been done for the most part, however, as an amelioratize measure to avoid the imposition of strict liability in connection with offenses which involve the public interest, but which differ in certain respects from 'public welfare offenses' in the classical sense. See, e.g., Lockyer v. Gibb, [1967] 2 ( .13. 243, and its sequel Warner v. Metropolitan Police Commissioner, [1968] 2 All E.R. 356 (H.L.), especially at 367. Aecord, Sivcet '. Parsley, [1969] 1 All E.R. 347 (H.L.). See also note 43 infra.

27. O. W. HolMes, supra note 10 , at Lec. II. 


\section{H. L. A. Hart's Theory of Negligence and Criminal Guilt}

According to H. L. A. Hart, there is nothing unjust, at least in ordinary circumstances where normal individuals are involved, in holding a person liable for some offense committed as the result of simple inadvertent negligence. His argument in support of this proposition proceeds as follows. It is a mistake to think that an individual is never responsible for some harm he has brought about just because he did not, at the time he acted, foresee it as either a necessary or probable consequence of his conduct. Foresight of consequences is not, as Turner and others believe, ${ }^{28}$ a necessary condition of criminal guilt. Often when a man has unintentionally caused injury, it is because he has failed either before acting or while acting to examine the situation he is in or to pay attention to what he is doing. It is these failures, when sufficiently unreasonable, that the law makes punishable when it adopts negligence as a subjective basis of liability. Surely there is a world of difference between this and the punishment of individuals who have brought about harm in situations where no exercise of reasonable care and attention could have prevented it. When the law does this, it imposes strict liability. But there is no reason to sny that the law also imposes strict liability every time it holds a person liable for failing to think about what he is doing and attending to the dangers he is creating. Of course there may be individuals who, for reasons of mental deficiency, cannot exercise even the lowest degree of care over their actions. To hold such individuals liable-in essence, for failing to do what they cannot do-rould be unjust and a reversion to strict liability. But where a man has the normal capacities required to think about his conduct and assess its risks, there is no good reason to excuse him for not doing so when harm results.

To understand the argument that Hart is making, it is necessary to see in detail both the analysis of negligence he is putting forward and the standard of criminal responsibility or guilt he is invoking. Both are of a highly original character. What makes harm caused by negligence culpable, according to Hart, is not the fact that the individual who brings it about does so without realizing what he is doing. It is not, as it were, his mere inadvertence or 'blank' state of mind with regard to the consequences of his conduct which makes him a fit subject for punishment. Rather, it is his failure to examine the situation he is in before acting and to assess its risks while acting, and so gelting into this 'blank' state of mind.

28. See Turner, supra note 12. 
Here it is important to pause and note that if anything is 'blameworthy', it is not the 'state of mind' but the agent's failure to inform himself of the facts and so getting inlo this 'state of mind'.=9

\section{And later:}

In ordinary English, and also in lawyers' English, when harm has resulted from someone's negligence, if we say of that person that he has acted negligently we are not thereby merely describing the frame of mind in which he acted. ... [W] are referring to the fact that the agent failed to comply with a standard of conduct with which any ordinary reasonable man could and would have complied: a standard requiring him to take precautions against harm. ... Very often if we are to comply with a rule or standard requiring us to take precautions against harm we must, before we act, acquire certain information: we must examine or advert to the situation and its possible dangers (e.g., see if the gun we are playing with is loaded) and watch our bodily movements (handle the gun carefully if it is loaded). . . . [N]egligence does not ... consist in [a] blank state of mind but in our failure to take precautions against harm by examining the situation. ${ }^{30}$

What Hart is suggesting here is that the duty to take reasonable precautions against harm, which is present as a subsidiary duty in connection with offenses such as manslaughter, extends not only to behavioral phenomena like 'shouting out a warning' or 'posting a danger sign' (as in the workman example set out above), but also to certain kinds of mental performances such as paying attention to what one is doing or adverting to the situation one is in and its possible risks. It is the individual's failure to perform these duties which results in his 'blank' state of mind with regard to the consequences of his conduct, and also which grounds his liability to punishment when negligence is a sufficient basis of liability in the criminal law. It is in respect of this failure that the individual is at fault. Thus, what Hart has done is to look 'behind' the negligent actor's inadvertence in order to find a mental failure on his part which is capable of supporting a judgment of culpability. This failure is the failure to exercise those of his mental capacities (e.g., of observation, thought, judgment, etc.) which are required to avoid causing harm. Of course, if the actor is a mentally deficient person and lacks one or more of these essential capacities, it would be unfair to subject him to penal liability since he could not exercise the kind of caution and supervision over his bodily move-

29. HART 146 .

30. Id. at $147-18$. 
ments which a normal person is capable of. On the other hand, if the actor was, as is generally true, a normal person, there is no good reason to excuse him from liability since he could have exercised the kind of care the law requires, and avoided causing harm.

What lies behind this analysis, and provides its cutting edge, is a thoroughly unusual conception of the 'subjective element' which is required for criminal responsibility. According to Hart, this element does not consist in what is usually termed 'guilty intent', i.e., knowledge of circumstances and foresight of consequences. These psycho. logical factors may be important as aspects of responsibility, but they are not in themselves essential. What is essential is that the individual, at the time he acted, possessed the normal capacities, both mental and physical, for conforming his conduct to the law's requirements. Strict liability, according to Hart, results only when an individual is held to a standard of performance which he is not capable of meeting. Thus, the important question raised by the mens rea requirement of AngloAmerican law is not whether the individual knew what he was doing at the time he acted, but whether he could have, by the use of his faculties, acted otherwise, and avoided causing harm.

Excessive distrust of negligence and excessive confidence in the respectability of "foresight of harm" or "having the thought of harm in the mind" as a ground of responsibility have their roots in a common misunderstanding. Both oversimplify the character of the subjective element required in those whom we punish, if it is to be morally tolerable, according to common notions of justice, to punish them. The reason why, according to modern ideas, strict liability is odious, and appears as a sacrifice of a valued principle ... is not merely because it amounts, as it does, to punishing those who did not at the time of acting "have in their minds" the elements of foresight or desire for muscular movement. These psychological elements are not in themselves crucial though they are important as aspects of responsibility. What is crucial is that those whom we punish should have had, when they acted, the normal capacities, physical and mental, for doing what the law requires and abstaining from what it forbids, and a fair opportunity to exercise these capacities. Where these capacities and opportunities are absent ... the moral protest is that it is morally wrong to punish because "he could not have helped it" or "he could not have done otherwise ...." 31

31. Id. at 152. It should be noted that in the passage quoted above professor Hart appears to suggest that criminal responsibility requires not only that an offender have had the capacity to conform his conduct to the law, but also that he have had a fair op. portunity to do so. This is the only point in Negligence, Mens Rea and Criminal Respoin. sibility in which Hart makes this suggestion, and it is not clear what importance, if any, he attaches to it. 
It is on the basis of this theory of criminal responsibility-what may be termed the 'capacities model'-that Hart maintains that punishment for negligence is not, at least in the vast majority of cases, where normal individuals are involved, a form of strict liability. ${ }^{32}$ It is important to notice, however, that Hart is not advancing this theory solely to deal with the problem of negligence. On the contrary, he obviously intends it as a general account of the notion of criminal guilt and of the claims of non-responsibility made by individuals under the doctrine of mens rea. ${ }^{33}$ Indeed, what makes Negligence, Mens Rea and Criminal Responsibility so important an article in the literature of jurisprudence is precisely the fact that it purports to resolve this basic and perplexing issue.

Whether the unusual account of criminal guilt it presents is in all respects adequate, however, is another question, and, surprisingly, one which has received very little attention from criminal law theorists. ${ }^{34}$ This is partly due, no doubt, to the highly abstract and elusive character of the issues involved. It is important to realize, however, that in all inquiries of this sort there is a touchstone in reality against which theory may be measured and evaluated. In the present case this touchstone is the institution of the criminal law and the discourse of moral claims which surrounds it. If Hart's thesis concerning the nature of criminal guilt-that it is essentially a matter of capacities-is correct, it should be capable of explaining at least the central practices of the criminal law which bear on the question of guilt, as well as the claims which surround these practices. In fact, as will be seen presently, there are a number of features of the criminal law of this sort which the 'capacities model' simply cannot explain; and this suggests that the model is, at least in certain respects, deficient. What is necessary, if a complete and satisfactory account of the notion of criminal guilt is to be achieved, is a more complicated explanation than that offered by Hart, an explanation centering on the notion of 'choice'. The precise details of this explanation, as well as its implications for the problem of negligence, will be presented in Section $V$ of this Note.

32. For the influence of this view, see note 14 supra.

33. Although Professor Hart never avows this 'generality of purpose' cxpressly, it may fairly be implied from a number of passages in Negligence, Mens Rea and Criminal Responsibility. See, e.g., HART 139 (where Professor Hart discusses his reasons for dealing at length with Dr. Turner's view regarding negligence) and 152. See also, id. at 227-30.

34. But see Fletcher, supra note 12; Hall, Negligent Dehavior Should Be Eiveluded From Penal Liability, 63 Colux. L. REv. 632, 635 n.19 (1963); and Wasserstrom, H.L.A. Hart and the Doctrines of Mens Rea and Criminal Responsibility, 35 U. CHI. L. REv. 92, $102-06$ (1967). 


\section{A Critique of Hart's Theory of Criminal Guilt}

If a theoretical account of the notion of criminal guilt is to be at all persuasive, it must be capable of explaining at least the standard cases of 'excuse' recognized by the law under the doctrine of mens rett. There are, however, at least two mental excusing conditions of this sort which cannot be explained in terms of the 'capacities model' advanced by Hart. The first of these is duress. Although Anglo-American law is somewhat sparse on the question of duress, there is recent English authority indicating that it constitutes a complete defense to a charge as serious as treason. ${ }^{35}$ Indeed, some American courts have gone beyond this, indicating a willingness, under certain circumstances, to accept duress as a defense even to a charge of murder. ${ }^{30}$ As a general matter, in order to make out a successful plea of cluress, a defendant must show that he was ordered to commit a certain offense and that he had reason to believe he would be killed or made to suffer serious bodily injury if he failed to comply. ${ }^{37}$ (Lesser threats have been accepted on a number of occasions. $)^{38}$ It is not necessary, however, to show that at the time the defendant was incapable of refusing or that in any way he was deprived of the capacity to order his conduct as the law requires. ${ }^{30}$ Moreover, it has been held that where no adequate threat of death or bodily injury is present a defendant may not introduce evidence of such incapacity (based on extreme weakness of will, shyness,

35. R. v. Purdy, 10 J. Crim. L. (Eng.) 182 (1946); R. v. Steane, [1947] K.B. 997. S'c also SMrTI \& Hocia 142-45 and WiLliams 752-53. Duress has long been recognized as a defense to treason in American law. See, e.g., Kawakita v. United States, 313 U.S. 717, 736 (1952).

36. See Paris v. State, 35 Tex. Crim. 82, 31 S.W. 855 (1895) and Joncs v. State, 207 Ga. 379, 62 S.E.2d 187 (1950). Both cases are cited in HAl. 439 n.95. In Sephakela v. R., 1 J. CRIM. L. (Eng.) 723 (1954), the l'rivy Council appears to have assumed that duress would be a defense to a charge of ritual murder in Basutoland, but it was not necessaty to decide the point.

37. See HAld 438-39 and R. Perkins, Criminal Law 954 (2d cd. 1969) [hercinafter cited as PERKINS].

38. See, e.g., Perryman v. State, $63 \mathrm{Ga}$. App. 819, 12 S.E.2d 388 (19.10), where the thicit of a prison guard to a youthful inmate to "make it hard for you; . I I will slap you down every time I see you" was held sufficient to constitute duress, although there was no suggestion that serious bodily injury was ever contemplated. See also Commonwealth $\checkmark$. Reffitt, 149 Ky. 300, 148 S.W. 48 (1912) (threat of "great injury, to person, reputation or property" held sufficient). Both cases stand for the proposition that where crimes le'ss serious than treason, burglary, arson, etc. are involved, threats of death or grievolis bodily injury are not necessary to establish duress. See l'ERKins 954.55.

39. Joncs v. State, 207 Ga. 379, 62 S.E.2d 187 (1950). Morcover, in many calses of dilless such a claim would be plainly untenable: for example, in a number of creason cases, the defendant's criminal conduct took place over a period of years. It is difficult to believe that anyone could be 'paralyzed by fear' for that length of time. Fithrther, a number of duress cases involve threats of a relatively minor character, threats sufficient to intiul. date perhaps, but hardly capable of depriving an individual of the ability to control his conduct. See note 38 supra.

For an older authority supporting this view of duress, see A. EAsr, $\Lambda$ I"kEAISE Of TIIL pleas of THE Crown 70.71 (1806). 
etc.) under the rubric of duress. ${ }^{40}$ The question of capacity or incapacity is simply not relevant to the issue of duress. The defense appears to rest on a quite different consideration: namely, that because the defendant was threatened with serious harm by another, he did not make a free choice to break the law.

Another well-established defense of the criminal law which, at least in its application to a wide range of offenses, makes no reference to the issue of capacity is mistake of fact."11 Thus, for example, if an individual takes or destroys the property of another in the honest, but mistaken, belief that it is his own, he is entitled, as a general matter, to be acquitted of theft or malicious destruction of property. ${ }^{2}$ It is no part of defendant's case to show that he was incapable of avoiding the mistake he made. It is enough that the mistake was an honest one, and that defendant's actions would have been innocent had the facts been as he believed them. Although serious inroads have been made on this rule in other contexts by American courts, it still prevails in the law of England, not only in connection with property offenses, but also with regard to such crimes as assault, battery, and malicious wounding. ${ }^{43}$ It is possible, of course, to argue that this is merely a display of generosity on the part of the law: that it might well and properly hold an individual liable every time he has failed to exercise his faculties to the fullest, and, as a result, brought about some form of prohibited harm. This argument, however, does not seem altogether persuasive. In the first place, many of the offenses which recognize mistake of fact as a defense involve quite serious forms of harm; ${ }^{\text {t4 }}$ and in such circumstances the law is rarely generous. More importantly, however, the argument appears to overlook the nature of the claim which is made by the individual in cases of mistake. That claim does not appear, at least on its face, to be one for mercy or generosity. On the contrary, it would seem that what the individual is contending in cases of mistake is that he is innocent: that because he acted under

40. Ross v. State, 169 Ind. 388, 82 N.E. 781 (1907) (threat of death held inadequate because too remote in time from commission of offeuse (arson)).

41. See generally S.Mrth \& Hogan 129-31; Cross \& JoNes 84-87; and Perkiss 939-43.

42. See Sistith \& Hogan 371, 461-62.

43. See id. at 252 (assault), 254 (battery), 266.68 (malicious vounding) in connection with material at 129. There are, of course, a number of offenses in Anglo-imerican law which require that a mistake of fact not only be honest, but also reasonable in order to excuse. The suggestion by some commentators that this represents the general or common law rule, however, seems unwarranted. See Wilson v. Injang. [19;1] 2 K.13. 799, and the opinion of Lord Reid in Warner v. Metropolitan Police Commissioner, [1968] 2 All E.R. 356 (H.L.), especially at 367 . See also note 26 supra.

44. E.g., arson (see PERKixs 218-20); mayhem (see id. at 184-89); assault, battery and malicious wounding (see note 43 supra). See also l'ERkiss 942 for additional crimes honor. ing the 'honest' mistake rule (perjury, forgery, receipt of stolen goods, etc.). 
a misapprehension and never chose to do anything wrong, he does not deserve to be punished.

A similar claim is often made by individuals who have engaged in some form of misconduct as the result of ignorance of the law. While such an excuse has never been allowed by English and American courts, ${ }^{45}$ it has rarely been denied, at least in the last century and a half, that this practice imposes a form of strict liability. ${ }^{40}$ The rationalc underlying this judgment seems reasonably straightforward: when a man has committed some offense as the result of ignorance of the law, it cannot be said of him-except, of course, where the offense is malum in se-that he chose to do something he knew to be wrong. It has never been suggested that the 'excuse' of ignorance of the law ought to apply only to cases where the accused, for one reason or another, could not have known what the law required of him. Such a small claim, tied to the notion of capacities, might have been admitted by Anglo-American law long ago. The fact is, however, that the moral protest which underlies the 'excuse' of ignorance of the law extends to a far wider set of cases. It is for this reason that the law has refused, on grounds of public policy, to accommodate it. ${ }^{47}$

Thus far the arguments advanced in this section against the 'capacities model' have dealt exclusively with the nature of certain claims of excuse commonly put forward in the criminal law. There is, however, another feature of the criminal law, impinging on the question of guilt, which points up the inadequacy of this model. It was noted earlier that the law frequently creates several offenses, all of which prohibit the same harm, but which vary in degree of seriousness according to the species of mental culpability involved. Thus, for example, the Model Penal Code recognizes three distinct forms of un* lawful homicide: murder (intention), manslaughter (recklessness), and negligent homicide, each of which carries a different maximum sentence. ${ }^{48}$ The reason for this is that each of these species of culpability involves a different degree of blameworthiness. If Hart's thesis concerning the nature of criminal guilt-that it is essentially a matter of capacities-is correct, however, this phenomenon is completely inexplicable. Since, ex hypothesi, in each case the actor possessed the same (normal) capacities, mental and physical, for avoiding harm,

45. See Smith \& Hogan 48-50. But cf. Lambert v. California, 355 U.S. 225 (1957). For a wide range of offenses, mistake of law, as distinguished from ignorance of law, is a valid defense. See SMith \& Hogan 50-51.

46. For some early theories attempting to justify the practice, see HALL 378.

47. See id. at 378-82.

48. Model PeNal CODE $\S \S 210.2,210.3,210.4$, and $\$ 6.06$ (Proposed Official Draft, 1962). 
and in each case the same harm was brought about through a failure to exercise these capacities as the law requires, there is no ground for distinguishing between cases. The actor's guilt, if guilt is a matter of capacities, must be the same in all.49 Yet the law has always insisted that the intentional offender is more blameworthy, and hence justly held liable to a harsher sentence, than the reckless offender. This fact can be explained only if the 'capacities model' of criminal guilt is abandoned, and a different model, centering on the notion of 'choice', is adopted in its place. If this is donc, it is immediately apparent why the law regards intentional harm-doing as more culpable than reckless harm-doing. In the first case, the actor has chosen to bring about harm while in the second he has chosen only to take a risk, albeit a substantial and unjustified risk, of doing so. There is no renson to excuse the reckless offender for what he has done, but it is clear, at least on grounds of blameworthiness, why he should be subjected to a less severe sentence than the intentional offender.

\section{The 'Choice Model'}

The theory of criminal guilt suggested above may now be presented in more complete and exact form. The theory is that, in essence, criminal guilt consists in the free choice of the individual to do something he knows to be wrong. This formula embraces three distinct elements which, taken together, constitute the core of the notion of mens rea or 'guilty mind'. The elements are: (1) that the individual made a choice to do something wrong, (2) that the choice was freely made (i.e., made in the absence of certain forms of coercion), and (3) that the individual knew or could appreciate the wrongness of what he

49. There is, moreover, a second problem of this gencral sort confronting l'rotessor Hart's theory. It often happens that an individual who sets out to commit a relatively minor offense will, because of some unforeseen circumstance, end up committing a crime of a far more serious character. In such cases the law is always faced with a problem: should the defendant be held only for the crime he intended to commit or should he be held for the maximum harm actually inflicted, even though such ham was unintended and genuinely unforeseeable at the time? Many times the law chooses the latter course, under the theory of 'transferred malice'. (Thus, if A sets out 10 commit grievons, but not lethal, bodily harm against $B$, and $B$ dies as a result, $A$ is guilty of murder.) Where a very great disparity exists in the relative gravity of the two offenses, however, the law may refuse to do this. Thus, if $A$ sets out to commit a 'technical' battery against in (say 'touching without consent') and has no desire to injure $B$ in any way, but $B$ dies as a result, $A$ cannot be convicted of murder or any other form of unlawful homicide. The law simply refuses to 'transfer malice' under these circumstances, on grounds that such action would be unfair. This phenomenon, straightforward as it may seem, is completely inexplicable under Professor Hart's theory. Assuming that the defendant had the capacity to avoid the underlying offense, there can be no reason for excusing him from all that resulted. The test of "capacities model" is simply met, and there is nothing more to be said. 
chose to do. Each of these elements exhibits a central feature of the concept of mens rea. Moreover, each element is discrete and necessary: none is subject to analysis in terms of some simpler or more comprehensive principle, and none may be dispensed with if a complete account of the notion of criminal guilt is to be achieved. Finally, each element must be present in any individual case of wrongdoing if mens $r e a$ is to exist. Thus, if an individual has broken the law, but can put forward an excuse (c.g., mistake, duress, insanity, etc.) which negatives one of the elements set out above, he has acted without mens rea. And, conversely, if he can put forward no such excuse, he must be deemed to have acted with mens rea.

Each of the excuses referred to above represents a kind of 'defecl' which may accompany the commission of a criminal act. These dcfects fall, broadly speaking, into two categories: (i) defects of voluntariness and (ii) defects of knowledge. Thus, it is sometimes said that the concept of mens rea has two distinct aspects, a voluntariness aspect and a cognitive aspect. From this point of view, each of the three elements set out above may be seen as establishing certain requirements (of voluntariness or knowledge or both) necessary for 'guilty mind', and it is only when these requirements are met-that is, when no defects or excusing conditions accompany the criminal act-that a mens rea is to be found. Although this is a useful way of viewing the problem, it is important to realize that the three elements do more ، than merely mirror or summarize the standard cases of excuse recognized by the criminal law. In addition, and more importantly, they provide a rationale for these excusing conditions. It is because a particular mental condition (e.g., mistake, duress, insanity, etc.) negatives one of the elements that it counts as an excuse. Thus, the three elements constitute a kind of model (the 'choice model') for explaining why the law honors a variety of different claims all of which bear directly on the question of guilt. These matters may be clearer, however, if each element is analyzed in terms of the specific cases of excuse or defect to which it relates.

\section{A. The First Element of Mens Rea}

The first element of mens rea-that the individual made a choice to do something wrong-is designed to account for both certain defects of voluntariness and certain defects of knowledge which may accompany the commission of a criminal act. The clearest example of a defect of the first sort is presented by the phenomenon of 'involuntary action' or, as it is sometimes referred to by English courts, 
'automatism'. Cases of involuntary action are generally divided by criminal law writers into two groups: (i) those in which the agent, though conscious, was deprived of the capacity to control his bodily movements (e.g., reflex, convulsion, etc.) and (ii) those in which the agent was simply unconscious at the time of his offense (e.g., somnambulism, blackout, etc.). ${ }^{50}$ Needless to say, in both sets of cases the individual is relieved of all criminal liability. The reason for this seems tolerably clear: in both sets of cases the agent's condition precludes the imputing of a choice to him, and where the element of choice is absent mens rea does not exist. In the first set of cases choice is precluded by the fact that the individual was umable to control the movements of his limbs at the time the offense took place. In the second set, it is precluded because the agent was unconscious, and hence no mind or 'will' capable of exercising choice is to be found.

A second defect of voluntariness which serves to negative the element of choice is 'irresistible impulse', a form of insanity widely recognized in the United States. ${ }^{52}$ Although the precise definition of irresistible impulse varies from jurisdiction to jurisdiction, the basic requirements of this defense are in general the same. ${ }^{.3}$ The accused must show that he suffered from some disease or defect of the mind which, at the time of his offense, deprived him of the power to govern his conduct and exercise the kind of self-control which normal people are capable of. In short, the accused must show that he had substantially lost the power to determine the course of his actions; that the balance of his mind was so disturbed that he was incapable of exercising choice, in any normal sense of the word. ${ }^{54}$ It is the loss of this. power of choice which precludes a finding of mens rea.

50. See generally HarT Ch. 4. Unconscious involuntary action may include acts purformed during natural sleep. See Boshears. (1961) The Times, February 18.

51. This may be so even where the offense charged is one of strict liability. See Hill v. Baxter, [1958] l Q.B. 277.

52. See generally A. Goldstein, TuE Insanity Defense Ch. 5 (1967). Irresistible impulse is expressly recognized as a form of insanity by the Model l'enal Coule. See MonkL PEvit. CODE \& 4.01 (Proposed Official Draft, 1962). Although irresistible impulse is not treated as a form of insanity under British law, the defense is granted limited recoguition under the rubric of "diminished responsibility", and also in the law of infanticide. Sec Sarm \& Hogan 124 and 240-41.

53. See GoldsteIN, supra note 52, at 69 .

54. In the more florid language of the court in the celebrated case of l'arsons v. State, 81 Ala. 577, 597, 2 So. 854, 866 (1887), the accused must show that (although he understood the criminal character of his conduct), he had "so far lost the pouter to choose between the right and wrong, and to avoid doing the act in question, ... that his frce agency was at the time destroyed ...." More contemporary statements of the rule do not require complete destruction of "free agency". The Model Pcnal Code, for examplc, requires only that the individual lacked "substantial capacity ... to conform his conduct to the ... law." Model Penal Code $\$ 4.01$ (l'roposed Ofíicial Draft. 1962). "The reason for this is simply that such 'substantial loss of control is sufficient to destroy "clioice' in the normal sense of the word, even though the individual may retain some capacity to govern his conduct. Compare this with P'rofessor Hart's account. 
There is thus a point in common between the defense of irresistible impulse and the two forms of involuntary action considered above: in all three cases (viz., conscious involuntary action, unconscious involuntary action, and irresistible impulse) it is the impossibility of imputing a choice to the defendant which provides the moral basis for his acquittal. It is important to notice, however, that these three excusing conditions are in all other respects quite different from one another. For example, it is generally not true in cases of irresistible impulse that the agent suffers any impairment of his capacity for muscular control, whereas this is always true in cases of conscious involuntary action. Conversely, in cases of conscious involuntary action, there is generally no loss by the agent of the capacity to make or form choices; the problem relates, rather, to the agent's physical ability to execute his choices. ${ }^{\overline{5}}$ And in cases of unconscious involuntary action, there is neither destruction of the power to makc choiccs nor of the power to execute them. The difficulty lies in the fact that the agent is unconscious, and hence no mind or 'will'-at least of the kind cognizable in moral theory-is present to which choices can be imputed. The point here is an important one, although one frequently overlooked by criminal law theorists: not all defects of voluntariness are the same. ${ }^{56}$ Nor are they necessarily even similar to any striking degree. As a general matter they bear only one feature in common. They all serve-each in its own way-to negative some essential element of mens rea, and thus to preclude a judgment of criminal responsibility. This matter will be considered again briefly later on in this section in connection with the defense of duress.

It was noted earlier that the first element of mens rea-that the individual made a choice to do something wrong-provides an account not only of certain defects of voluntariness commonly recognized in the criminal law, but also of certain defects of knowledge. The two clearest examples of this latter sort of defect are (i) mistakc of fact and (ii) failure to foresee consequences. Although the first of these excusing conditions was discussed at length in Section IV, some of what was said may be worth repeating here. When an individual has

\footnotetext{
55. For an excellent account of the different stages of action at which different excuses come into play, see J. L. Ausrin, $A$ Plea for Excuses, in Cortegred l'Alens 123 (1961).

56. For a classic example of this mistake, see Commonwealth v. Rogers, 7 Met. 500, 502 (Mass. 1844), where Chief Justice Shaw in explaining the defense of irresistible Iill. pulse states the following: "If then it is proved ... that the mind of the accused was ill at diseased and unsonnd state, the question will be . . . . whether the prisoner, in committing the homicide, acted from an irresistible and uncontrollable impulse: If so, then the act was not the act of a voluntary agent, but the involuntary act of the body, willout tho concurrence of ' $a$ mind directing it" (emphasis added).
} 
broken the law as the result of a mistake of fact, he is, as a general matter, relieved of all criminal liability-provided, of course, that his actions would have been innocent had the facts been as he believed them. A defendant will gain no advantage by proving that he did not intend to shoot Smith but rather Jones who looks just like him. The rationale underlying this rule appears to rest on the following consideration: when a man has broken the law solely as the result of an innocent mistake, he cannot be said to have chosen to do something wrong, and where no such choice is present, mens rea does not exist. Precisely the same analysis may be applied to cases where the agent was not laboring under any particular mistake of fact, but simply failed to foresee what the consequences of his conduct would be; or where because of a mistake of fact such foresight was lacking. In both these cases, as in the case of mistake simpliciler, the defendant's claim is essentially the same: that as he did not realize what he was doing at the time he acted, and never chose to do anything wrong, he does not deserve to be punished.

Moreover, a similar claim appears to underlie the defense of insanity as defined by the first of the M'Naghten Rules. According to that Rule, an accused is entitled to acquittal if, at the time of his offense, he was suffering from "such a defect of reason, from disease of the mind, as not to know the nature and quality of the act he was doing ...." "st Disease of the mind is not, in itself, a defense to a criminal charge under the M'Naghten Rules. The accused must show in addition that such disease deprived him of the capacity to understand the physical character of his acts, and it is this which constitutes the specific ground of exculpation. Moreover, the judges in M'Naghten's Case also made clear that where the defendant did understand the nature of his conduct, but acted under the influence of an insane delusion' as to the circumstances he was in, he is entitled to acquittal only if his actions would have been innocent had the facts been as he believed them. ${ }^{58}$ In short, an accused is entitled to acquittal under the first of the M'Naghten Rules only in those cases where it is impossible to impute a choice to do something wrong to him. The Rule thus appears to be aimed at precisely the same consideration which underlies the rule with respect to mistake. In both cases, it is the innocence of the defendant's choices which precludes a finding of mens rea.

57. M'Naghten's Case, $10 \mathrm{Cl}$ \& Fin. 200, 210 (1843). The second of the ML'Naghten Rules is discussed later on in this section.

58. Id. at 211 . 


\section{B. The Second Element of Mens Rea}

Thus far consideration has been given in this section solely to those cases of excuse or defect which serve to negative the first element of mens rea, that the individual made a choice to do something wrong. There are, however, a number of cases in which it would be inappropriate to punish even though such a choice is present. And these cases serve to point up additional requirements implicit in the concept of 'guilty mind'. One such requirement is embodied by the second element of mens rea, that the individual's choice was freely made. This requirement is designed to account for certain defects of voluntariness which result from coercion. The leading (and perhaps only remaining) example of such a defect in Anglo-American law is duress.

As was noted in Section IV, when an individual has broken the law solely as the result of threats made against him, he is as a general matter entitled to acquittal. The reason for this seems tolerably clear: where such circumstances exist, the individual's choice cannot be deemed to have been freely made, and where no free choice is present mens rea does not exist. The defect involved in cases of duress is, of course, one of voluntariness. So much may be implied from the idea of coercion. It is important to notice, however, that this defect is not of the same kind as those considered earlier in the cases of involun. tary action and irresistible impulse. In those latter cases, the gist of defendant's excuse was that, because of some mental condition, he could not be said to have chosen to do something wrong. This is generally not the case in duress since, except in those rare instances where the individual is literally paralyzed by fear, there is no loss by the actor of either the power to make or execute choices. Threats-unlike in voluntary muscular reactions and 'irresistible impulses'-are not inherently destructive of choice. ${ }^{59}$ Rather, to speak accurately, they render the individual's choice unfree in the sense that he has been compelled by another person, in a position of dominance over him, to act against his will.

It is this kind of compulsion to act 'against one's will' which lies at the heart of the notion of coercion. And such a defect has long been recognized as sufficient to negative mens rea. Indeed in earlier times, at least one other form of coercion-apart from duress-was expressly recognized as a defense in the criminal law. This was the defense of 'marital coercion', and although its precise scope was never fully defined, there can be little doubt as to the problem with which it was

59. See p. 968 supra. 
meant to deal. At common law, a wife who committed an offense in the presence of her husband was presumed to have acted under such coercion as to entitle her to acquittal. ${ }^{00}$ No showing of threats or other forms of physical duress was necessary since the kind of 'dominance' involved was assumed to arise naturally from the marital relation. The coercion was moral in character, but not without force. Indeed, the sole means by which the prosecution might rebut the presumption of marital coercion was to prove that the wife had taken an independent part' in the commission of the offense. ${ }^{01}$ In other words, if it could be clearly shown that the wife had not been made to act 'against her will', but had engaged in the crime voluntarily or 'on her own initiative', then, and only then, was a judgment of mens rea possible.

The particular social conditions which gave rise to the defense of marital coercion have, of course, all but disappeared. The broader principle underlying the defense, however, remains an integral part of the concept of 'guilty mind'. Coercion-whatever its form-is no less inconsistent with the idea of mens rea now than it was a century or five centuries ago. This is, in substance, the point behind the defense of duress, a defense which-despite the trend toward absolute liability in modern criminal law-shows every sign of expansion. The defense displays vitality exactly because the claim upon which it rests continues to possess moral force. It is, in the final analysis, the innocence of those who have committed crimes under compulsion which shields them from the sanctions of the law.

\section{The Third Element of Mens Rea}

It has been suggested thus far that the idea of mens rea embraces two basic requirements: (I) that the individual made a choice to do something wrong and (2) that the choice was freely made. There is, however, one further requirement necessary to complete the picture, and it is provided by the third element of mens rea: that the individual knew or could appreciate the wrongness of what he chose to do. This requirement is designed to account for certain defects of knowledge which have long been recognized as excusing conditions in the criminal law. Perhaps the clearest example of such a defect is provided by the ancient defense of infancy.

At common law, a child beneath the age of seven was incapable

60. See Smith \& Hogan 145-47; Williams 762-63; and Perkiss 909-18.

61. See Williams 763 and Perkins 915. 
of committing a crime. ${ }^{62}$ The reason invariably given for this is that a child of such tender years cannot know the difference between right and wrong, and is, consequently, incapable of "contracting guilt". ${ }^{.3}$ In the somewhat stylized language of the common law, such a child was said to be doli incapax or "incapable of mischief". A child beyond the age of seven, but who had not yet reached fourteen, was similarly presumed at common law to be doli incapax. The presumption was rebuttable, but only upon a specific showing that the child had achieved 'moral discretion', i.e., that he possessed at the time of the offense a substantial ability to understand the moral character of his actions. ${ }^{64}$ In short, unless it could be shown that the child knew or could appreciate the wrongful character of what he had chosen to do, a finding of mens rea was impossible.

Precisely the same principle at stake in the defense of infancy may be seen as well in the defense of insanity as defined by the second of the M'Naghten Rules. According to the Rules, an accused is entitled to acquittal if, at the time of his offense, he was suffering from "such a defect of reason, from disease of the mind, as not to know the nature and quality of the act he was doing, or, if he did know it, that he did not know he was doing what was wrong." ${ }^{55}$ It is not sufficient for responsibility under the M'Naghten Rules that the defendant knew or understood the physical character of his conduct. Even if this were true, the Rules define a second, and quite separate, ground of excuse: that the defendant, by reason of mental disease, did not know that what he was doing was wrong. Where such knowledge is absent, it is immaterial that the accused knew or comprehended the physical nitture of his actions since it is clear that despite this he could not appreciate the significance of what he had chosen to do. Thus, as in the case of infancy, a judgment of mens rea is, by the nature of things, precluded. It has been suggested above, in Section IV, that a similar consideration underlies the usually unacceptable 'excuse' of ignorance of law.

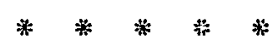

This is the structure of the 'choice model' of criminal guilt. It consists, as the reader will no doubt have already perceived, of three distinct elements each of which is designed to explain one or more of the standard cases of excuse recognized by the criminal law under the

62. See SMIth \& Hogan 110; WiLliams 814; and Perkins 837.

63. 4 W. Blackstone, Commentaries *23.

64. See Smith \& Hogan 111-12 and Perkins 839.

65. M'Naghten's Case, $10 \mathrm{Cl}$. \& Fin. 200, 210 (1843) (emphasis added). For an excellent elucidation of the meaning of this requirement, see the opinion of Cardozo, J. in l'cople v. Schmidt, 216 N.Y. 324 (1915), especially at 329.40 . 
doctrine of mens rea. As was noted at the outset of this section, these excusing conditions divide, generally speaking, into two groups: (i) those which relate to the voluntariness with which the defendant acted, and (ii) those which relate to the state of the defendant's linoul$e d g e$ at the time he acted. As a consequence of this the 'choice model' may be said to have, as an explanatory theory, two distinct components: a voluntariness component and a cognitive component, corresponding to the two principal aspects of the concept of mens rea. From this point of view, the essence of the dispute between the 'choice model' and the general theory of responsibility advanced by Professor Hart is that Hart has, in the 'capacities model', eliminated allogether the cognitive aspect of mens rea and also that part of the voluntariness aspect of mens rea (represented by excuses such as coercion and duress) which cannot be explained in terms of 'capacity' or 'incapacity'. For Professor Hart, it will be remembered, actual knowledge of the nature and consequences of one's actions and an actual choice to do something wrong are not essential for 'guilty mind'. All that is essential is that the individual have had at the time of his offense all those capacities, both mental and physical, necessary for conforming his conduct to the requirements of the law. It is only when an individual lacks some such capacity-that is, when he is incapable of avoiding illegal conduct -that he may claim to be without guilt. What this means is that, for Hart, all excuses in the criminal law are essentially of one form: they are claims of 'incapacity' of one sort or another. There are, of course, a number of excusing conditions, well established in the criminal law, which meet this form. These are excuses such as 'involuntary action' and 'irresistible impulse' which consist essentially in defects of voluntariness amounting to 'incapacity'. There are, however, a number of excusing conditions, equally well established in the criminal law, which do not. These are excuses such as 'mistake of fact' which do not relate to voluntariness, but rather which imply certain requirements of knowledge generally thought to be integral to the concept of 'guilty mind'. To meet this problem what Hart has done is simply replaced these requirements of actual knowledge by the general requirement of 'capacity to know': so that if an individual could have known that he was about to engage in some form of unlawful conduct-i.e., if he possessed all those capacities of observation, thought, etc., required for such knowledge-he must be deemed a fit subject for liability. And the reason for this is simply that if the individual could have known the nature of his offending conduct, he also could have avoided it. 
Professor Hart's analysis is thus reductionist in character. For the complex notion of 'choice', a notion which embraces elements of both voluntariness and knowledge, Hart has substituted the simpler notion of 'capacity' which is an important category (although only one of scveral important categories) of the concept of voluntariness. The difficulty with this approach is that by reducing 'choice' to 'capacity to avoid unlawful conduct', Hart has rendered himself incapable of explaining a whole set of features of the criminal law which bear directly on the question of guilt. And, of course, as has been shown in Section IV, these features represent precisely those aspects of the concept of mens rea which cannot be explained in terms of 'capacity' or 'incapacity'. This general result is not altogether surprising. Indeed it is the frequent fate of reductionist analyses: the explanatory formula is so neat and simple that the author overlooks the fact that it will not explain all that it is supposed to. But surely the principal measure of a theory is its ability to explain. When a theory fails to account for all the phenomena it is meant to, it is at best incomplete. At worst it is inaccurate and misleading. This latter, unhappily, is the case with Professor Hart's theory; for not only is the 'capacities model' incapable of explaining a number of important features of the concept of criminal guilt, but in attempting to do so it actually distorts the principles and claims underlying these features. Thus, Professor Hart makes it appear that all claims raised under the doctrine of mens rea are essentially of one type, viz., claims of incapacity, when in fact they are of a variety of types and aimed at a variety of principles all quite distinct from one another.

Finally, it follows from the general analysis of this section that when an individual has broken the law as the result of simple inadvertent negligence he has acted without mens rea. This is so because it is exactly in the case of 'negligence', as distinguished from 'intention' and 'recklessness', that there is no choice by the actor to do something wrong. Indeed, half the point of saying that an offense was committed through negligence is expressly to exclude this possibility. Thus, to adopt negligence as a basis of liability in the criminal law is, necessarily, to revert to a standard of strict liability and to eliminate that 'subjective element' which, under modern notions of justice, makes punishment tolerable.

\section{Negligence, Mens Rea, and Ordinary Language}

At the root of Professor Hart's views with regard to 'negligence' and mens rea lie a number of considerations of a broadly theoretical chan- 
acter concerning the subject of responsibility generally, and no treatment of Hart's work in this area would be complete without providing some account of these basic considerations. Professor Hart's position with respect to 'negligence'-that it is, essentially, a form of 'guilty mind'-derives at root from a philosophical analysis of the 'discourse of excuses' which exists in ordinary language. The aim of this analysis is to disclose, by an examination of excuses, and particularly of the circumstances in which certain excuses are 'unacceptable', the standards of responsibility invoked in ordinary social life when one individual has, by his outward conduct, caused some sort of harm or injury to another. Thus, Hart begins his essay Negligence, Mens Rea and Criminal Responsibility with the following significant passage:

"I didn't mean to do it: I just didn't think." "But you should have thought." Such an exchange, perhaps over the fragments of a broken vase destroyed by some careless action, is not uncommon; and most people would think that, in ordinary circumstances, such a rejection of "I didn't think" as an excuse is quite justified. No doubt many of us have our moments of scepticism about ... the whole business of blaming and punishment; but if we are going in for the business at all, it does not appear unduly harsh, or a sign of archaic or unenlightened conceptions of responsibility, to include gross, unthinking carelessness among the things for which we blame and punish. ${ }^{60}$

The method of analysis employed by Hart in this passage was first suggested by the late $\mathrm{J}$. L. Austin, ${ }^{07}$ and the theory behind it may be simply stated in the following terms. It is a characteristic of all, or nearly all, excuses that under certain circumstances they will be 'unacceptable': that the claims they embody will be rejected. By exam. ining these excuses as they exist in ordinary language and the circumstances in which they are commonly rejected, it is possible to isolate and identify the standards of responsibility employed by ordinary men in everyday social life. Thus, if "I didn't mean to do it: I

66. Hakr 136.

67. See Austin, supra notc 55 , at 142-43:

Standards of the unacceptable. It is characteristic of excuses to be 'unacceptable': given, I suppose, almost any excuse, there will be cases of such a hind or of such gravity that "we will not accept" it. It is interesting to delect the standards and codes we thus invoke. The extent of the supervision we excrcise over the execution of any act can never be quite unlimited, and ustally is expected to fall within fairly definite limits ('due care and attention') in the case of acts of some general kind, though of course we set very different limits in different cases. W' may plead that we trod on the snail inadvertently: but not on a babj-jou ought to look where you are putting your great fect. Of course it was (really), if you like, inadicrtence: but that word constitutes a plea, which is not going to be allowed, because of standards. And if you try it on, you will be subscribing to such drcadful standards that jour last state will be worse than your first (emphasis added in part). 
just didn't think" is not, under ordinary circumstances, an acceptable excuse when harm has resulted from some thoughtless action, this suggests that there is nothing inappropriate, at least under ordinary conceptions of responsibility, in blaming a man and holding him accountable for such harm. And, to complete the argument, if such standards of responsibility prevail in the world of ordinary social judgments, there appears to be no reason why they should not also be applied in the law. "After all," as Hart points out somewhat later, "a hundred times a day persons are blamed outside the law courts for" not being more careful, for being inattentive and not stopping to think ...." Why then should these same negligent omissions, when sufficiently gross, not provide a suitable basis for criminal liability? Of course there may be individuals who, for reasons of mental deficiency, cannot exercise even the lowest degree of care over their actions, and it would be wrong to punish such individuals for their shortcomings. But where a man possesses the normal capacities required to think about his conduct and the risks he is creating, and fails to exercise these capacities, there is no good reason to excuse him from liability when harm results.

It is this analysis which underlies Professor Hart's general position with regard to criminal responsibility: that it consists essentially in a failure to exercise those capacities of observation, thought and control over conduct necessary to meet the law's requirements, and not essentially in 'foresight of consequences' or an actual choice to do something wrong. But if this argument is correct, an anomalous situation results since it seems reasonably clear from the analysis undertaken in Section V that such a choice is an essential requirement of mens rea as that concept has been developed in the practices of the criminal law. This anomaly may be dissolved, however, if one rather traditional assumption of legal philosophy is abandoned: and that is that the term 'responsibility' must have a single and uniform menning, i.t., that whatever 'responsibility' means, and whatever 'subjective conditions' it entails, it must mean the same thing and entail the same conditions in all contexts and for all purposes. And, conversely, that whatever amounts to strict liability in one context must also amount to strict liability in every other. For this restrictive view however there seems little justification, as the following modest observations may make plain.

The practice of 'blaming', as it exists in ordinary life, is not a simple

68. HART 151. 
affair. Nor does it exist in isolation from other social practices concerned with the appraisal of human conduct and, particularly, with the making of judgments of responsibility with regard to such conduct when it results in some form of harm or injury. These latter practices, moreover, although intimately connected with 'blaming', do not end in mere criticism. Rather they proceed to far more serious and tangible consequences. One such practice is, of course, punishment. Another, no less fundamental-and, perhaps, more familiar in ordinary lifeis the practice of making individuals pay compensation when they have caused some kind of harm or injury to others. Both these practices are, of course, formalized in the law: the former in the criminal law and the latter in the law of tort. Both, moreover, involve the imposition of liability on individuals for the harm they cause for the most part on the basis of judgments of responsibility. And, as a consequence of this, both may be said to involve 'blaming' of one sort or another. Yet the standards of responsibility employed by each of these practices-that is, the 'subjective conditions' required for a judgment of responsibility in each-are quite different. In the criminal law, as was noted in Section V, a judgment of mens rea or 'guilty mind' requires, as a minimum, a finding that the defendant made a choice to do something wrong. In the law of tort, on the other hand, the base-line standard of responsibility or 'fault' is negligence, and this requires only a finding that the defendant, whether intentionally or not, engaged in some act which a reasonable man would not have performed given all the circumstances. This basic difference in standards of responsibility between the criminal law and the law of tort is, of course, a commonplace to most practicing lawyers; and few of them would suggest, for example, that because the law of tort requires only negligence for responsibility, and not a conscious choice by the defendant to do something wrong, that it amounts essentially to a system of strict liability. On the contrary, most of them would say that where the issue in a case is compensation, as it is in all cases in tort, negligence or simple 'fault' is enough for the proper imposition of liability; but that where punishment is involved something more than this-a conscious choice by the defendant-should be required.

The reason for this basic distinction is not very difficult to see: it relates to the differences in purpose associated with the practice of punishment, on the one hand, and the practice of enforced compensation on the other, and to the differences in the equilable claims involved in each of these practices. When an accident has occurred, and some form of harm or injury has been inflicted, someone must bear 
the loss. And, if the defendant was at all at fault-say, because he failed, although not deliberately, to take some elementary precaution which any reasonable man could and would have taken-there seems no renson why he should not be made to compensate the plaintiff for the harm done. In such cases the defendant is held essentially for his failure to exercise adequate caution, for not paying sufficient attention to what he was doing and for failing to exercise those of his other mental capacities (e.g., of observation, thought, etc.) necessary to avoid causing injury to others. It is upon these 'failures' that the plaintiff's claim to reparation is based, ${ }^{60}$ and it is the principal purpose of the law of tort to deal with such claims and to award compensation when it is merited. The criminal law, on the other hand, has no such function; nor is it concerned with claims of this sort. The sole purpose of the practice of punishment, as it exists in the criminal law, is to teach the offender a lesson and to deter him and others-by using his misfortunes and disgrace as a public example-from engaging in unlawful conduct in the future. This, of course, is strong stuff, and most people would think that it requires for a justification, if it con be justified at all, something more than the kind of 'fault' associated with 'not paying sufficient attention to what one is doing' or 'not stopping to think' or one of a hundred other inadvertent omissions so common in ordinary experience. It is true, of course, that when liability in tort is based upon 'fault' of this kind a deterrence mechanism similar to that which exists in punishment is also created, and it may be admitted, at least arguendo, that an auxiliary purpose of the 'fault system' is to deter individuals from dangerous conduct by making it both expensive and embarrassing. But even if this is so, it still remains true that liability in tort, unlike criminal liability, is imposed only where and to the extent necessary to compensate a victim for the injury he has suffered. Punishment, on the other hand, by its very nature goes beyond this because it imposes liability even where there is no injury to be compensated or when compensation has already been made, and because it does this in all cases solely for the purpose of 'teaching the offender a lesson' and 'making an example of him for the benefit of others' so that the general 'system of threats' by which society maintains order will not drop below an acceptable level of efficacy. This is the meaning of penal liability, and the moral protest involved when such liability is imposed for negligence is simply that the defendant does not deserve to be subjected to this-that is, to the

69. This is not to suggest that there may not be other kinds of claims to compensation properly recognized in the law of tort. 
added burdens of imprisonment or fine and the disgrace and stigma which invariably accompany them-unless he has made a conscious choice to do something he knew to be wrong.

This is a perfectly coherent and straightforward claim, and it is one which the criminal law by and large respects. Indeed, it is this claim which provides the moral foundation upon which the whole doctrine of mens rea rests. Nor is there any inconsistency in maintaining this view, on the one hand, and acknowledging, on the other, that where practices other than punishment are concerned, involving other purposes and other claims, something less may be sufficient for an 'assignment of blame' and for the proper imposition of liability. Indeed, to take such a position is only to acknowledge that standards of responsibility may vary from one practice to another, and that what constitutes an 'excuse' in one social context may not in another. And surely this is not so very great a concession to make to the richness and complexity of human social life. The ways in which an individual mny compromise himself morally are many and diverse; but it is only when a man has brought upon himself the worst sort of blame, by freely choosing to do something he knows to be wrong, that the suffering and humiliation of punishment may in all conscience be applied. 